and characters has enriched the English language. Kelsie Harder has emphasized that Dickens was a master at concocting names with tonal and allegorical qualities and the "inimitable" Victorian could not have been the novelist he was without these names, which contributed so much to his popularity and somehow fixed forever in the English language such names as Gradgrind, Pickwick, Bounderby, Pecksniff, Gamp, Dombey, Micawber, Posnap, Weller. And what is more, these names have been prolific: Pecksniff (in Martin Chuzzlewit) has generated at least the following forms: Pecksniffery, Pecksniffism, Peckniffianly, Pecksniffingly; Micawber (in David Copperfield) has also been prolific: Micawberish(ly), Micawberism, Micawberite; Gradgrind (in Hard Times) has produced Gradgrinding, Gradgrindism; Podsnap (in Our Mutual Friend) has three derivations: Podsnappery, Podsnap(p)ian, Podsnapism; Weller (in Pickwick Papers) has produced the term Wellerism and two adjectives: Welleresque and Wellerian.

In Dr. Donald Hawes's Who's Who in Dickens we miss some of the brilliant advances of those researchers who have delved into the fascinating world of the origin and meaning of the Dickensian characters. Among these contributions we should include Kelsie Herder, "Charles Dickens Names His Characters," Names 7 (March 1959): 35-42; Stanley Gerson, "Name-Creation in Dickens," Moderna Sprak 69.4 (1975): 299-315; Stephen R. Rounds, "Naming People: Dickens's Technique in Hard Times," Dickens Studies Newsletter 8.2 (June 1977): 36-40; Knud Sorensen, Charles Dickens: Linguistic Innovator (Arkona: Aarhus Universitet, 1985). Through this help, students and lovers of Dickens's fiction will be in the fortunate position of discovering the calculated and careful process adopted by the novelist in the creation of names as a technique to portray typical behaviour or typical qualities.

Adolfo Luis Soto Vázquez

Charles Dickens. Hard Times. Intr., glossary, and notes by Adolfo Luis Soto Vázquez. La Coruña: Servicio de Publicaciones de la Universidad de La Coruña, 1996.

The University of La Coruña Press has recently released a new edition of Hard Times, one of Dickens's most accomplished works and a sui generis representative of the so-called "Condition-of-England novel," which, in Victorian times, portrayed the evils of industrialism, the unfairness of economic laissez-faire, the suffering of the working classes, and, in the particular case of this novel, the inadequacy of an educational system based exclusively on the utilitarian handling of facts. This edition is the more welcome because it does not attempt to compete with other scholarly editions of Dickens's novels; rather, it has been designed as a students' text from the outset and exhibits every feature we have come to associate with books of this kind. First, it should be pointed out that it is not headed by a lengthy and heavy-going introduction. Instead, the reader finds a series of short sections entitled "Hard Times as a Weekly Serial," "Background," "Criticism," "The Naming of Characters," "Lancashire Dialect," "Circus Slang," and "The Education System," all of them, as can be seen, directly relevant to the main stylistic and thematic aspects of Dickens's novel. In "Hard Times as a Weekly Serial," Dr. Soto Vázquez 
examines the process of publication of Hard Times and how its final title came to be chosen among fourteen alternatives; in "Background," there is a selection of letters about Hard Times addressed by Dickens to Victorian intellectuals and men of letters such as John Forster, Mark Lemon, Peter Cunningham, Charles Knight, and Thomas Carlyle; in "Criticism," we find three critical excerpts about this novel by Hippolyte Taine, John Ruskin, and F. R. Leavis; and so forth. The section called "The Education System" is of particular interest because Hard Times notoriously combines a critique of the working conditions in the nineteenth-century industrial city of Preston - under the fictitious name of Coketown-with an indignant satire on the education given to young children in the Gradgrind school following the wake of Jeremy Bentham's utilitarian philosophy.

Apart from these introductory sections, Dr. Soto Vázquez's edition is complemented by a chronology of Charles Dickens's life and publications, a glossary of Lancashire dialectal forms, substandard words and circus slang, a fourteen-page section of explanatory notes to the text of Hard Times, and a substantial bibliography. Fifteen years after the publication of Dr. López Ortega's edition of Hard Times by Alhambra in 1981, this new edition of Dickens's classic novel stands out as a valuable addition to the array of annotated and commented English literary texts now available to Spanish university students.

José Antonio Álvarez Amorós

\section{J. A. Hurtley, B. Hughes, R. M. González Casademont, I. Praga y E. Aliaga. Diccionario cultural e histórico de Irlanda. Barcelona: Ariel, 1996.}

In the introduction to the book the authors refer to the increasing interest in everything related to Ireland and her culture over the last few decades.The film industry, musical groups and leading literary figures have helped to forge a new image of Ireland. Films like The Quiet Man or The Commitments, celtic groups like The Chieftains or Enya, writers like Yeats, Joyce, Beckett, or Seamus Heaney, each from their own viewpoint contributed to expose one side of Ireland, a small but tremendously complex country. They also complain that some quarters in English Studies are reluctant to admit certain Irish writers belong to an Irish literary tradition, with Harold Bloom's The Western Canon as just one significant example. Besides, as far as Spain is concerned, there is an almost complete ignorance of Irish affairs beyond what is highlighted in the media which produces a distorted vision of real Ireland.

The dictionary is precisely aimed at filling that gap. It is really a most interesting and helpful reference book which will be essential for the student, the ordinary reader interested in Ireland, and the scholar alike. Perhaps, one is somewhat surprised at the beginning to find the items in English when the book is in Spanish. The explanation to that is given in the introduction; however, to a certain extent, that involves a fairly high knowledge of English and ordinary readers might be discouraged by this way of presenting the information. The contents provide very important definitions and explanations of Irish cultural and historic events, mainly devoted to the 20th century, although that does not mean that references to the past are ignored. In fact, anyone 